Case 2

A 32 year old Asian man presented with a three week history of poor appetite, weight loss, diarrhoea, sweating, tremor of the hands, and paraesthesia in the extremities and face. Symptoms developed four weeks after treatment for eczema had been started by the same hakim who had treated the first patient.

On examination the patient was anxious, flushed, tachycardic, and hypertensive, with a fine tremor of the outstretched hands. Neurological examination showed reduced pinprick sensation in both feet. Standard laboratory investigations, including thyroid function tests, all gave normal findings. Mercury poisoning was confirmed by a urinary mercury concentration of $105 \mu \mathrm{g} / \mathrm{l}$ (normal $<10 \mu \mathrm{g} /$, toxic concentration $>100 \mu \mathrm{g} / \mathrm{l}) 12$ weeks after the last exposure to the ethnic remedies. Analysis of the handmade redbrown pills which the hakim had prescribed at a dose of six daily showed each to contain $30-42 \mathrm{mg}$ of inorganic mercuric sulphide (table).

\section{Comment}

Both our patients presented with symptoms and signs of heavy metal intoxication within six weeks of exposure to remedies administered by the same hakim. The presentation of the first patient with a subacute sensorimotor peripheral neuropathy is typical of intoxication with inorganic arsenic.' Peripheral neuropathy after use of arsenic containing ethnic remedies has been reported from India, ${ }^{2}$ but is not a recognised health hazard in the United Kingdom. The symptoms in case 2, which included gastrointestinal and autonomic disturbance, closely resembled those reported in past cases of mercury intoxication. ${ }^{13}$

Most large towns in Britain with sizable Asian communities have three or four resident hakims, and an unknown number visit Britain from abroad to practise for a few weeks several times a year. The hakim who treated these two patients was a visitor.
Most hakims are medically unqualified and the main conditions they treat are fatigue and depression, digestive disorders, psychosexual problems, and skin conditions. ${ }^{4}$ The services of hakims and the products used by them are widely advertised in Asian newspapers in Britain. Some hakims manufacture their own remedies from raw materials bought in India, whereas others obtain commercial preparations directly from manufacturers in India or Pakistan. Many are issued in unlabelled containers.

As illustrated by the first patient, recovery from arsenical neuropathy is generally poor, even after treatment with chelating agents. ${ }^{5}$ Prompt removal from the source of toxic exposure is therefore mandatory. Of greater concern is the fact that a single dose of arsenic trioxide of 200-300 mg may be fatal. ${ }^{6}$ Since one of the preparations given to the first patient contained up to $187 \mathrm{mg}$ of arsenic trioxide per dose, there is a potential for fatal poisoning. To prevent further cases the Indian community in the United Kingdom should be made aware of the risks associated with the use of ethnic remedies, and their distribution and sale should be monitored.

We thank Dr J Meadway for allowing us to report one of her patients, Mr I House for performing the toxicological assays, and Detective Constable G Hamilton of Southall police.

1 Windebank AJ, McCall JT, Dyck PJ. Metal neuropathy. In: Dyck PJ, Thomas PK, Lambert EH, Bunge R, eds. Peripheral neuropathy. Philadelphia: Saunders, 1984:2133-61.

2 Chhuttani PN, Chawla LS, Sharma TD. Arsenical neuropathy. Arch Neurol 1967;17:269-74.

3 Kark RAP. Clinical and neurochemical aspects of inorganic mercury intoxication. In: Vinken PJ, Bruyn GW, eds. Handbook of clinical neurology. Vol 36. Amsterdam: Elsevier, 1979:147-97.

4 Healy MA, Aslam M. Asian healers in Britain. The Asian community: medicines and traditions. Huddersfield: Silver Link, 1990.

5 Murphy MJ, Lyon LW, Taylor JW. Subacute arsenic neuropathy: clinical and electrophysiological observations. $f$ Neurol Neurosurg Psychiatry and electrophysiog.

6 Kaye S. Arsenic. In: Snyder LM, Turner RF, Wilson CM, Wilson ON, Fisher RS, eds. Handbook of emergency toxicology. Springfield, Illinois: Thomas, 1977:148-54

(Accepted 2 October 1992)

\title{
Pituitary imaging is essential for women with moderate hyperprolactinaemia
}

\author{
P M Stewart, S Maheshwaran, J Griffith, J Li, M C Sheppard, J Olliff, J A Franklyn
}

All women with hyperprolactinaemia (>1000 mU/l) should be referred for further assessment and computed tomography or magnetic resonance imaging of the pituitary
In patients with a macroadenoma $(>1 \mathrm{~cm}$ in diameter) of the pituitary a plasma prolactin concentration of $>4000 \mathrm{mU} /,{ }^{1}>6000 \mathrm{mU} /{ }^{2}{ }^{2}$ or $>8000 \mathrm{mU} /{ }^{3}$ has been reported to be diagnostic of a prolactin secreting adenoma. A plasma prolactin concentration which is raised but is less than this can originate from a small prolactin secreting tumour (microadenoma) or from loss of normal inhibitory control by dopamine, as seen in compression of the pituitary stalk. This secondary hyperprolactinaemia usually indicates the presence of a large pituitary tumour not secreting prolactin or a cyst.

TABLE I-Plasma prolactin concentrations and presenting symptoms in 36 patients with hyperprolactinaemia according to appearance of pituitary on computed tomography

\begin{tabular}{|c|c|c|c|c|c|}
\hline \multirow[b]{2}{*}{ Tomographic appearance } & \multirow{2}{*}{$\begin{array}{c}\text { Median (range) } \\
\text { plasma prolactin } \\
(\mathrm{mU} / \mathrm{l})\end{array}$} & \multicolumn{4}{|c|}{ No with symptoms } \\
\hline & & $\begin{array}{l}\text { Oligomenorrhoea } \\
\text { and amenorrhoea }\end{array}$ & Galactorrhoea & Headache & Tiredness \\
\hline Normal $(n=12) \dagger$ & $\begin{array}{l}2125(1100-3900) \\
2447(1079-4200)\end{array}$ & 10 & $\begin{array}{l}6 \\
6\end{array}$ & 3 & 1 \\
\hline $\begin{array}{l}\text { Microadenoma }(\mathrm{n}=18) \\
\text { Macroadenoma }(\mathrm{n}=6)\end{array}$ & $\begin{array}{l}2447(1079-4200) \\
2491(1003-7180)\end{array}$ & $\begin{array}{r}11 \\
5\end{array}$ & $\begin{array}{l}0 \\
2\end{array}$ & $3 \star$ & $3^{\star \star \star}$ \\
\hline
\end{tabular}

tIncludes one report of an empty sella.

Compared with other patients (Fisher's test of exact probability): ${ }^{\star} \mathrm{p}<0.05,{ }^{\star} \mathrm{p} p<0.01$.
Hartog and Hull stated that computed tomography of the pituitary does not have a role in cases of moderate hyperprolactinaemia ${ }^{4}$ because it is of little value in diagnosing a microadenoma. 5 They have, however, overlooked the possibility of moderate hyperprolactinaemia reflecting compression of the pituitary stalk. We assessed the prevalence of large tumours in patients with moderate hyperprolactinaemia.

\section{Methods}

We studied 36 women (mean (SD) age $30 \cdot 8(8 \cdot 2)$ years) who presented with oligomenorrhoea, amenorrhoea, infertility, or galactorrhoea to an endocrine or infertility clinic over two years and who had a plasma prolactin concentration of $1000-8000 \mathrm{mU} / \mathrm{l}$ (normal range 80-460 $\mathrm{mU} / \mathrm{l}$ ). We excluded women with hypothyroidism and with hyperprolactinaemia related to drug treatment. We recorded the patients' presenting symptoms and checked their visual fields with a confrontation test. Computed tomography of the pituitary was performed on all patients, and all the scans were reported by two consultant radiologists by consensus. Contiguous $2 \mathrm{~mm}$ coronal (or axial) scans 
Endocrine Clinic and

Department of Radiology, General Hospital,

Birmingham B6 4NH

P M Stewart, lecturer in medicine

$S$ Maheshwaran, registrar in radiology

J Griffith, registrar in

radiology

$\mathrm{J} \mathrm{Li}$, consultant radiologist

M C Sheppard, professor of medicine

J Olliff, consultant radiologist

J A Franklyn, senior lecturer

in medicine

Correspondence to:

Dr P M Stewart,

Department of Medicine,

University of Birmingham,

Queen Elizabeth Hospital,

Birmingham B15 2TH.

$B M F$ 1993;306:507-8

TABLE II-Details of patients identified as having macroadenoma

\begin{tabular}{|c|c|c|c|c|c|}
\hline $\begin{array}{l}\text { Case } \\
\text { No }\end{array}$ & $\begin{array}{c}\text { Age } \\
\text { (years) }\end{array}$ & $\begin{array}{l}\text { Plasma } \\
\text { prolactin } \\
(\mathrm{mU} / \mathrm{l})\end{array}$ & Presenting symptoms & Finding on pituitary scanning & Treatment and progress \\
\hline 1 & 20 & 1003 & $\begin{array}{l}\text { Amenorrhoea, left sided headache, } \\
\text { tiredness }\end{array}$ & $18 \times 14 \mathrm{~mm}$ intrasellar tumour & Surgery-removal of dermoid cyst \\
\hline 2 & 19 & 5680 & Amenorrhoea & $\begin{array}{l}\text { Large tumour extending to left } \\
\text { cavernous sinus and carotid artery }\end{array}$ & $\begin{array}{l}\text { Bromocriptine-no response; } \\
\text { craniotomy-removal of tumour weakly } \\
\text { staining for prolactin }\end{array}$ \\
\hline 3 & 43 & 1202 & Amenorrhoea, headache, tiredness & $\begin{array}{l}\text { Large tumour extending to left } \\
\text { temporal lobe }\end{array}$ & $\begin{array}{l}\text { Craniotomy-removal of non-functioning } \\
\text { chromophobe }\end{array}$ \\
\hline 4 & 16 & 1210 & $\begin{array}{l}\text { Galactorrhoea, left sided headache, } \\
\text { tiredness }\end{array}$ & $11 \mathrm{~mm}$ tumour eroding sellar floor & $\begin{array}{l}\text { Bromocriptine-no response; surgery- } \\
\text { removal of non-functioning } \\
\text { chromophobe }\end{array}$ \\
\hline 5 & 21 & 7810 & Ameporrhoea, galactorrhoea & $11 \mathrm{~mm}$ tumour & $\begin{array}{l}\text { Bromocriptine-prolactin concentration } \\
\text { normalised }\end{array}$ \\
\hline 6 & 28 & 3720 & Amenorrhoea & $10 \mathrm{~mm}$ tumour eroding sellar floor & $\begin{array}{l}\text { Bromocriptine-prolactin concentration } \\
\text { normalised }\end{array}$ \\
\hline
\end{tabular}

were obtained after injection of intravenous contrast medium. In patients identified as having a macroadenoma visual fields were confirmed by Goldmann perimetry.

\section{Results}

The mean plasma prolactin concentration in the 36 women was 2492 (range 1003-7180) $\mathrm{mU} / \mathrm{l}$. All the women had full visual fields. Pituitary scans were reported as normal in 11 cases and as showing an empty sella in one, a microadenoma in 18, and a macroadenoma in six (table I). Among the patients with apparently normal pituitaries or a microadenoma the highest prolactin concentration was $4200 \mathrm{mU} / \mathrm{l}$. Headache and tiredness were more common presenting complaints in patients with a large tumour, although thyroid and adrenal function was normal in this group. Secretion of growth hormone was not assessed.

In two of the patients identified as having a macroadenoma (cases 5 and 6) tumours, 10 and $11 \mathrm{~mm}$ in diameter, behaved as typical prolactinomas: menses were restored and plasma prolactin concentration was normalised by treatment with the dopamine agonist bromocriptine (table II). The four other patients almost certainly had secondary hyperprolactinaemia, which in cases 2,3 , and 4 was associated with invasive non-functioning pituitary macroadenomas.

\section{Discussion}

Although treatment of secondary hyperprolactinaemia with a dopamine agonist may reduce plasma prolactin concentrations, it has little or no effect on the growth of a macroadenoma. If the tumour is left untreated local invasion may cause compression of the optic chiasm with subsequent loss of vision. Furthermore, although our patients were not deficient in adrenocorticotrophic or thyroid stimulating hormone, a full endocrine assessment is essential to screen for potentially life threatening hypopituitarism. We conclude that all women with documented moderate hyperprolactinaemia should be referred, through a specialist, for routine computed tomography (or, where available, magnetic resonance imaging) of the pituitary. This is essential if cysts or pituitary macroadenomas not secreting prolactin are to be identified and treated appropriately.

1 Nabarro JDN. Pituitary prolactinomas. Clin Endocrinol 1982;17:129-55.

Ross RJM, Grossman A, Bouloux P, Rees LH, Doniach I, Besser GM. The relationship between serum prolactin and immunocytochemical staining for prolactin in patients with pituitary macroadenomas. Clin Endocrinol 1985;23:227-35.

3 Bevan JS, Burke CW, Esiri MM, Adams CBT. Misinterpretation of prolactin levels leading to management errors in patients with sellar enlargement. $A m \mathcal{F}$ Med 1987;82:29-32.

4 Hartog M, Hull MGP. Hyperprolactinaemia. BMf 1988;297:701-2.

5 Teasdale E, Teasdale G, Mohsen F, Macpherson P. High resolution computed tomography in pituitary microadenoma: is seeing believing? Clin Radiol tomography in pitil

(Accepted 30 September 1992)

\section{A PAPER THAT CHANGED MY PRACTICE}

\section{Elegant, epidemiological, and in English}

As a medical student and then junior doctor I could never understand the fascination that more senior doctors had with research. I was more interested in trying to hear a diastolic murmur, and, after I entered psychiatry, eliciting first rank symptoms. Research was what my superiors did when they should have been teaching me. When I was interviewed at the Maudsley Hospital in London I professed a strong commitment to research (to say anything else would have been fatal), but underneath my heretical beliefs remained firm. It was not until I read Lee Robin's paper summarising a series of studies on the epidemiology and aetiology of adult antisocial behaviour that I appreciated the sheer beauty and elegance that research could bring.' I realised that I could never achieve such heights, but I knew what I should aspire to.

Like many pieces of significant research it began with a serendipitous finding. Dr Robins stumbled across the complete prewar records of local child guidance clinics which were about to be destroyed. She set about, and completed, a follow up study of what had happened to these children. From this came a series of major papers outlining the continuities and discontinuities between childhood and adult behaviour and thus vital observations on the aetiology of adult antisocial behaviour.

These were seminal studies, but that was not why the paper held my attention. It was because this paper, which contained a précis of the findings, had all the characteristics of what I now know to be a classic paper. ${ }^{2}$ The subject was important. The paper was short, elegant, and free from jargon. The methods were clear and made sense. The research was statistically based, but statistics were used to enlighten and not bore. There were few references. I had read many papers in English, but this was the first in clear English.

From it I took three messages. Firstly, clinical research, which is what I decided to do, is an epidemiological discipline. Secondly, longitudinal studies are its most powerful tool. Thirdly, it is a crime to destroy medical records.- SIMON WESSELY is a senior lecturer in psychological medicine in London

Robins L. Sturdy childhood predictors of adult antisocial behaviour: replications from longitudinal studies. Psychol Med 1978;8:611-22. 2 David A. How to write a classic paper. BMY 1990;300:30-1. 